\title{
The protective effect of taurine and/or vanillin against renal, testicular, and hematological alterations induced by potassium bromate toxicity in rats
}

\author{
Enas Ali Kamel Mohamed* and Eman Ali saddek
}

\begin{abstract}
Background: Potassium bromate $\left(\mathrm{KBrO}_{3}\right)$ causes toxicity in humans and experimental animals. The wide exposure to $\mathrm{KBrO}_{3}$ in water disinfection and as a food additive necessitates finding of available antidotes for its hazards as taurine and/or vanillin.

Aim: The present study was conducted to investigate the protective effects of taurine and/or vanillin against potassium bromate toxicity on renal, testicular, and hematological parameters in adult male albino rats.

Methods: For this purpose, 30 rats were divided as follows: control group, rats were fed balanced diet and served as normal control; group 2, rats were fed balanced diet and served as positive control; group 3, rats were fed balanced diet supplemented with taurine (100 mg/kg diet); group4, rats were fed balanced diet supplemented with vanillin (100 mg/kg diet); and group5, rats were fed balanced diet supplemented with taurine and vanillin at the same tested dose for 3 weeks. Groups from 2 to 5 were orally administered a single dose of $\mathrm{KBrO}_{3}$ (100 mg/kg diet) then sacrificed after 48 h.

Results: Results showed that $\mathrm{KBrO}_{3}$ administration induces testicular damage reflected in a significant decrease in total protein, glycogen, sialic acid with a significant increase in MDA level in testicular tissue. Also, there was a significant decrease in total spermatic count accompanied by an increase in the total number of malformed sperms (head, tail, and head and tail) in the pot bromate intoxicated group. Also, $\mathrm{KBrO}_{3}$ toxicity induce renal damage manifested in a significant increase in serum urea, creatinine, uric acid, and xanthine oxidase activity. Renal TNF-a, IL-6, Hcy, and MDA significantly increased in the pot-bromate intoxicated group. Finally, hematological results showed a significant decrease in $\mathrm{Hb} \%, \mathrm{MCV}, \mathrm{RBC}$, and WBCs count in the pot-bromate intoxicated group as compared to normal control groups. Histological findings showed that impaired renal and testicular histology was concomitant with biochemical parameters. Conclusion: Treatment with taurine and/or vanillin showed a significant ameliorative effect against deleterious effects of pot bromate toxicity on hematological parameters, renal and testicular tissues. Moreover, the recorded improvement of the studied parameters in rats pretreated with taurine and vanillin as antioxidants proves their synergistic effect.
\end{abstract}

Keywords: Potassium bromate, Toxicity, Taurine, Vaniline, Protective effect, Rats

\footnotetext{
* Correspondence: enas.elbakry@ymail.com

Biochemistry and Nutrition Department, Faculty of women for Art, Science

and Education, Ain Shams University, Cairo, Egypt
} 


\section{Background}

Potassium bromate $\left(\mathrm{KBrO}_{3}\right)$ is used as a food additive. It acts for giving elasticity and strength to the dough during the baking process. It also used in beer making, cheese production, and is usually added to fish paste products. Additionally, it is used in pharmaceutical industries and cosmetics (Ahmad \& Mahmood, 2016 Oloyede \& Sunmonu, 2009).

Bromate is now considered as a human and animal carcinogen. Reactive oxygen species (ROS) and free radicals have been implicated in mediating $\mathrm{KBrO}_{3}$-induced toxicity. These radicals can induce tissue damage by reacting with macromolecules like proteins, nucleic acids, and lipids, which leads to tissue injury Ahmad et al., 2012 and 2013).

Vanillin (4-hydroxy-3-methoxybenzaldehyde) is the main constituent of vanilla. It is a phenolic phenylpropane C6-C1 carbonic structural derivative. It is found in many essential plant oils, principally Vanilla pompon, Vanilla planifolia, and Vanilla tahitensis (Priefert, Rabenhorst, \& Steinbuchel, 2001). It is widely used in processed foods, pharmaceutical products, and in perfume (Zamzuri \& Abd-Aziz, 2013). Previous studies showed that vanillin has antioxidant, anti-inflammatory, anti-carcinogenic, and inhibition mutagenesis (Bezerra, Nascimento Soares, \& de Sousa, 2016).

Taurine is a sulfur-containing amino acid present in almost all animal tissues, most abundantly as a free intracellular amino acid in human cells (Kim, Gupta, \& Lee, 2007). It is involved in numerous biological and physiological functions that exert important health benefits. Taurine acts as a cytoprotective agent in a variety of tissues. It also modulates a variety of cellular functions, including conjugation of bile acids, anti-oxidation, osmoregulation, modulation of ion movement, and modulation of neurotransmitters (Lourenco \& Camilo, 2002). Also, taurine protects tissues from various pathological conditions resulting from free radicals generated upon exposure to various xenobiotics (Das et al., 2011).

Although many lines of substantiation supporting the beneficial effects of either vanillin or taurine against pathological conditions resulting from free radicals generated upon exposure to various xenobiotics, the synergistic effect of vanillin and taurine against renal, testicular, and hematological alterations have not been yet thoroughly investigated. Therefore, the present study was attempted to assess the protective effect of taurine and /or vanillin against $\mathrm{KBrO}_{3}$ toxicity on hematological parameters, renal and testicular tissue in experimental rats.

\section{Materials and methods}

\section{Chemicals}

$\mathrm{KBrO}_{3}$ was purchased from Alpha Chemika, India. Taurine and vanillin were purchased from Sigma Chemical CO, USA. All chemicals were of analytical grade.
Kits

Glycogen kits were purchased from Genway Biotech, INC, USA. The total sialic acid kit was purchased from Cell Biolabs, Inc., USA.Urea, creatinine, uric acid, and total protein kits were purchased from DIACHEM Ltd., Budapest, Attila. Xanthine oxidase and rats ELISA kits were purchased from CUSABIO, China. Tumor necrosis alpha (TNF- $\alpha$ ) and interleukin-6 (IL-6) enzyme immunoassay kits were purchased from IBL Co., Ltd. Japan. Malondialdehyde (MDA) kit was purchased from Cell Biolabs, Inc., USA.

\section{Animals}

Forty adult male, Wistar strain albino rats weighing $(200 \pm 5 \mathrm{~g})$ were purchased from a breeding unit of Medical Research Center (Faculty of Medicine, Ain Shams University). The rats were housed in individually under a controlled condition of temperature (25 $\left.\pm 5{ }^{\circ} \mathrm{C}\right)$, humidity $(50 \pm 10 \%)$, and acclimatized to $12 \mathrm{~h}$ light/dark. The experimental period was 23 days on which food and water were provided ad libitum. An animal experiment was conducted according to the guidelines of the institutional animal ethics committee.

\section{Diet}

The basal diet was based on AIN-93 recommendations according to (Reeves, Nielsen, \& Fahey, 1993).

\section{Experimental design}

The animals were randomly assigned into five experimental groups (each of eight). All international and local rules and regulation for handling animals in experiments were followed. The experimental groups illustrated as follows:

Control group: rats were fed the balanced diet and served as normal control.

Group 2: rats were fed the balanced diet and served as positive control.

Group 3: rats were fed balanced diet supplemented with taurine (100 mg/kg diet for 3 weeks (El-Houseini, El-Agoza, Sakr, \& El-Malky, 2017).

Group4: rats were fed balanced diet supplemented with vanillin $(100 \mathrm{mg} / \mathrm{kg}$ diet for 3 weeks (Shoeb, Chowta, Pallempati, Rai, \& Singh, 2013).

Group5: rats were fed balanced diet supplemented with taurine and vanillin at the same tested dose for 3 weeks. Groups from 2 to 5 were orally administered a single dose of $\mathrm{KBrO}_{3}$ (100 mg/kg body weight) then sacrificed after $48 \mathrm{~h}$ (Ahmad, Naqshbandi, Fareed, \& Mahmood, 2012).

At the end of the experiment, the animals were anesthetized with diethyl ether after $12 \mathrm{~h}$ fasting and whole 
blood samples were taken from the hepatic portal vein. The blood samples were divided into two tubes, the first tube contained EDTA for determination of blood picture. Blood sample in the second tube left for $15 \mathrm{~min}$ at $37^{\circ} \mathrm{C}$ for serum separation, then centrifuged at $3000 \mathrm{rpm}$ for $20 \mathrm{~min}$, then sera were separated and kept in plastic vials at $-20{ }^{\circ} \mathrm{C}$ until analyses. Kidney and testis were removed, rinsed with cold saline, and dried with filter paper.

\section{Preparation of testis homogenate}

The tests were weighed and homogenized in ice-cold $0.25 \mathrm{M}$ sucrose solution $(1: 5 w / v)$. The homogenates were centrifuged at $1500 \mathrm{rpm}$ for $10 \mathrm{~min}$ in a refrigerated centrifuge TDL-5000B (Shanghai Anke company, Ltd., China). The supernatant was collected and stored frozen for analysis.

\section{Preparation of kidney homogenate}

Kidneys were weighed and homogenized in cold $5 \mathrm{~mm}$ sodium phosphate buffer. The homogenates were centrifuged at $1500 \mathrm{rpm}$ for $15 \mathrm{~min}$ at $4{ }^{\circ} \mathrm{C}$, and the supernatant was collected and stored frozen for analysis.

\section{Sperm count and morphology}

The two cauda-epididymis from each rat were dissected; each of them was minced in $2 \mathrm{ml} 0.9 \% \mathrm{NaCl}$. The semen was carefully mixed; the epididymal fluid was subjected to sperm count using Neubauer hemocytometer (Belsey et al., 1980). Films were spread on clean dray slides, left to dry, and stained with HX\&E stain for the examination of sperm morphology.

\section{Biochemical assays}

Total protein was analyzed by standard spectrophotometric methods according to Henry, Cannon, and Winkelman (1974). Glycogen was measured using a quantitative colorimetric method of Dalrymple and Hamm (1973); a total sialic acid kit was determined according to the calorimetric method as described by (Yao, Obuka, Mosuka, Kinuta, \& Ikeda, 1989). Serum urea, creatinine, and uric acid were determined calorimetrically according to
Tobacco, Meiattini, Moda, and Tarii (1979), Rock, Walker, and Jennings (1987), and Barham and Trinder (1972), respectively. Xanthine oxidase activity was measured by ELISA using rat xanthine oxidase ELISA Kits, catalog no, CSB-E13614r, according to the manufacturer's instructions. Levels of TNF- $\alpha$ and IL- 6 were measured using rat ELISA kits with monoclonal antibodies specific for rat TNF- $\alpha$, and IL- 6 according to Beutler, Greenwald, and Hulmes (1985) and Wong and Clark (1988) following manufacturer's instructions. Homocysteine was measured by ELISA using rat homocysteine ELISA kit, catalog no, CSB-E13376r according to the manufacturer's instructions. MDA was determined calorimetrically according to (Ohkawa, Ohishi, \& Yagi, 1979).

\section{Hematological analysis}

Whole blood samples were analyzed with an automatic Vet abcTM Animal Blood Counter (Horiba ABX, Montpellier, France) using the hematology kits specified in that instrument (HoribaABX, France) according to the manufacturer's instructions.

\section{Histopathological examination}

Kidney and testis were dissected and fixed at 10\% neutral formalin fixative and tissues were processed and stained with hematoxylin and eosin (H\&E) and examined under a light microscope.

\section{Statistical analysis}

The data were presented as means $\pm \mathrm{SD}$. One-way analysis of variance (ANOVA) followed by post-hoc least significant difference analysis (LSD) at $(p<0.05)$ was performed using the statistical package for social science (SPSS) version 9 to compare all treated groups. Differences were considered to be significant when $(p<0.05)$.

\section{Results}

Results showed in Table 1 demonstrated that $\mathrm{KBrO}_{3}$ administration induces testicular damage reflected in a significant decrease in total protein, glycogen, and sialic acid in

Table 1 Effect of taurine and/or vanillin on total protein, glycogen, total sialic acid content, and malondialdheyde (MDA) activity in testes of the potassium bromate-treated rats

\begin{tabular}{lllll}
\hline Groups & Parameters & & & \\
\cline { 2 - 5 } & Total protein $(\mathrm{mg} / \mathrm{g})$ & Glycogen $(\mathrm{mg} / \mathrm{g})$ & Total sialic acid $(\mathrm{mg} / \mathrm{g})$ & $\mathrm{MDA}(\mu \mathrm{mol} / \mathrm{g})$ \\
\hline Control & $4.22 \pm 0.09 \mathrm{a}$ & $2.66 \pm 0.07 \mathrm{a}$ & $4.20 \pm 0.03 \mathrm{a}$ & $0.11 \pm 0.01 \mathrm{a}$ \\
Pot.bromate group & $2.9 \pm 0.05 \mathrm{~b}$ & $1.82 \pm 0.037 \mathrm{~b}$ & $2.70 \pm 0.16 \mathrm{~b}$ & $0.34 \pm 0.02 \mathrm{~b}$ \\
Pot.bromate + taurine group & $3.38 \pm 0.09 \mathrm{c}$ & $2.26 \pm 0.07 \mathrm{c}$ & $3.40 \pm 0.19 \mathrm{c}$ & $0.24 \pm 0.01 \mathrm{c}$ \\
Pot.bromate + vanillin group & $3.25 \pm 0.41 \mathrm{c}$ & $2.29 \pm 0.13 \mathrm{c}$ & $3.43 \pm 0.15 \mathrm{c}$ & $0.25 \pm 0.01 \mathrm{c}$ \\
Pot bromate + taurine + vanillin group & $3.65 \pm 0.11 \mathrm{~d}$ & $2.52 \pm 0.06 \mathrm{~d}$ & $3.84 \pm 0.08 \mathrm{~d}$ & $0.18 \pm 0.015 \mathrm{~d}$ \\
\hline
\end{tabular}

Values are expressed as mean \pm S.D., $n=6$

There was no significant difference between means have the same letter in the same column 
Table 2 Effect of taurine and/or vanillin on spermatic count of the potassium bromate-treated rats

\begin{tabular}{llllll}
\hline Groups & Parameters & & & \\
\cline { 2 - 6 } & Total no of sperm & Total no of abnormal sperm & Malform head & Malform tail & Malform head + tail \\
\hline Control & $943 \pm 4.1 \mathrm{a}$ & $90 \pm 2.0 \mathrm{a}$ & $53 . \pm 2.0 \mathrm{c}$ & $20.33 \pm 0.5 \mathrm{c}$ & $16.66 \pm 0.6 \mathrm{~b}$ \\
Pot.bromate group & $579.66 \pm 11.5 \mathrm{~b}$ & $183 \pm 4.0 \mathrm{~b}$ & $131.33 \pm 2.8 \mathrm{a}$ & $33 \pm 2.0 \mathrm{a}$ & $19.66 \pm 0.6 \mathrm{a}$ \\
Pot.bromate + taurine group & $676 \pm 8.5 \mathrm{c}$ & $152.66 \pm 3.5 \mathrm{c}$ & $100.66 \pm 1.5 \mathrm{a}$ & $33 . \pm 1.7 \mathrm{a}$ & $19 \pm 1 \mathrm{a}$ \\
Pot.bromate + vanillin group & $636.3 \pm 14.04 \mathrm{~d}$ & $154.66 \pm 2.5 \mathrm{c}$ & $103.33 \pm 2.8 \mathrm{a}$ & $32.6 \pm 1.5 \mathrm{a}$ & $18.33 \pm 0.57 \mathrm{a}$ \\
Pot bromate + taurine + vanillin group & $796.33 \pm 12.3 \mathrm{e}$ & $111.33 \pm 3.0 \mathrm{~d}$ & $67.66 \pm 3.1 \mathrm{~b}$ & $26 \pm 1.7 \mathrm{~b}$ & $18.0 \pm 0.1 \mathrm{a}$ \\
\hline
\end{tabular}

Values are expressed as mean \pm S.D., $n=6$

There was no significant difference between means have the same letter in the same column

Table 3 Effect of taurine and/or vanillin on serum urea, creatinine, uric acid, and renal-homocysteine of the potassium bromatetreated rats

\begin{tabular}{lllll}
\hline Groups & Parameters & & \\
\cline { 2 - 5 } & Urea $(\mathrm{mg} / \mathrm{dl})$ & Creatinine $(\mathrm{mg} / \mathrm{dl})$ & Uric acid $(\mathrm{mg} / \mathrm{dl})$ & Xanthine oxidase $(\mu \mathrm{g} / \mathrm{mg}$ protein/min) \\
\hline Control & $13.9 \pm 0.34 \mathrm{~d}$ & $0.36 \pm 0.01 \mathrm{~d}$ & $2.03 \pm 0.05 \mathrm{~b}$ & $1.16 \pm 0.08 \mathrm{~d}$ \\
Pot.bromate group & $36.1 \pm 0.46 \mathrm{a}$ & $0.82 \pm 0.03 \mathrm{a}$ & $3.93 \pm 1.4 \mathrm{a}$ & $2.29 \pm 0.06 \mathrm{a}$ \\
Pot.bromate + taurine group & $27.2 \pm 0.8 \mathrm{~b}$ & $0.64 \pm 0.02 \mathrm{~b}$ & $1.96 \pm 0.28 \mathrm{~b}$ & $1.70 \pm 0.04 \mathrm{~b}$ \\
Pot.bromate + vanillin group & $27.1 \pm 0.34 \mathrm{~b}$ & $0.63 \pm 0.02 \mathrm{~b}$ & $1.61 \pm 0.17 \mathrm{~b}$ & $1.78 \pm 0.03 \mathrm{~b}$ \\
Pot bromate + taurine + vanillin group & $20.20 \pm 0.86 \mathrm{c}$ & $0.44 \pm 0.02 \mathrm{c}$ & $1.76 \pm 0.23 \mathrm{~b}$ & $1.5 \pm 0.015 \mathrm{c}$ \\
\hline
\end{tabular}

Values are expressed as mean \pm S.D., $n=6$

There was no significant difference between means have the same letter in the same column

Table 4 Effect of taurine and/or vanillin on tumor necrosis factor-a (TNF-a), interleukins-6 (IL-6), homocysteine (Hcy), and malondialdehyde (MDA) in kidney of the potassium bromate-treated rats

\begin{tabular}{llll}
\hline Groups & \multicolumn{2}{l}{ Parameters } & \\
\cline { 2 - 4 } & TNF- $\mathrm{a}(\mathrm{ng} / \mathrm{g})$ & $\mathrm{IL}-6(\mathrm{ng} / \mathrm{g})$ & $\mathrm{Hcy}(\mu \mathrm{mol} / \mathrm{g})$ \\
\hline Control & $2.22 \pm 0.09 \mathrm{~d}$ & $4.71 \pm 0.11 \mathrm{c}$ & $3.82 \pm 0.11 \mathrm{~d}$ \\
Pot.bromate group & $5.22 \pm 0.10 \mathrm{a}$ & $7.7 \pm 0.23 \mathrm{a}$ & $7.6 \pm 0.55 \mathrm{a}$ \\
Pot.bromate + taurine group & $4.14 \pm 0.09 \mathrm{~b}$ & $6.01 \pm 0.18 \mathrm{~b}$ & $5.9 \pm 0.23 \mathrm{~b}$ \\
Pot.bromate + vanillin group & $4.1 \pm 0.97 \mathrm{~b}$ & $6.1 \pm 0.07 \mathrm{~b}$ & $6.09 \pm 0.11 \mathrm{~b}$ \\
Pot bromate + taurine + vanillin & $3.27 \pm 0.13 \mathrm{c}$ & $4.29 \pm 1.8 \mathrm{~d}$ & $5.07 \pm 0.16 \mathrm{c}$
\end{tabular}

Values are expressed as mean \pm S.D., $n=6$

There was no significant difference between means have the same letter in the same column

Table 5 Effect of taurine and/or vanillin on RBCS count, Hb\%, Hct, MCV, and MCH values in the potassium bromate-treated rat

\begin{tabular}{|c|c|c|c|c|}
\hline \multirow[t]{2}{*}{ Groups } & \multicolumn{4}{|l|}{ Parameters } \\
\hline & $\operatorname{RBCS}(106 / \mu \mathrm{l})$ & $\mathrm{Hb} \%$ & $\mathrm{Hct}$ & MCV \\
\hline Control & $6.51 \pm 0.93 a$ & $10.05 \pm 0.21 \mathrm{a}$ & $28.7 \pm 2.2 \mathrm{a}$ & $60.31 \pm 2.2$ \\
\hline Pot.bromate group & $2.89 \pm 1.2 b$ & $7.0 \pm 2.2 b$ & $15.3 \pm 2.3 b$ & $53 \pm 2 b$ \\
\hline Pot.bromate + taurine group & $5.07 \pm 2.04 \mathrm{a}$ & $8.5 \pm 1.9 a$ & $25.4 \pm 2.7 \mathrm{a}$ & $55.9 \pm 0.01 \mathrm{c}$ \\
\hline Pot.bromate + vanillin group & $5.77 \pm 2.1 \mathrm{a}$ & $9.7 \pm 1.95 \mathrm{a}$ & $31.5 \pm 2.4 \mathrm{a}$ & $55 \pm 1.89 a$ \\
\hline Pot bromate + taurine + vanillin & $4.51 \pm 2.03 \mathrm{a}$ & $8.3 \pm 2.1 \mathrm{a}$ & $26.5 \pm 2.04 a$ & $59 \pm 2.4 \mathrm{a}$ \\
\hline
\end{tabular}

Values are expressed as mean \pm S.D., $n=6$

There was no significant difference between means have the same letter in the same column 
Table 6 Effect of taurine and/or vanillin on MCH, MCHC values, platelet, and WBCs counts in the potassium bromate-treated rats

\begin{tabular}{|c|c|c|c|c|}
\hline \multirow[t]{2}{*}{ Groups } & \multicolumn{4}{|l|}{ Parameters } \\
\hline & $\mathrm{MCH}(\mathrm{Pg})$ & $\mathrm{MCHC}(\mathrm{g} / \mathrm{dl})$ & Platelet count $(103 / \mu l)$ & WBCs count $(103 / \mu l)$ \\
\hline Control & $20.5 \pm 2$ a & $31.6 \pm 1.7 \mathrm{a}$ & $34.99 \pm 1.99 a$ & $2.3 \pm 0.2$ \\
\hline Pot.bromate group & $17.04 \pm 2.07 \mathrm{a}$ & $33.00 \pm 2 \mathrm{a}$ & $31.03 \pm 0.55 a$ & $1.5 \pm 0.5 b$ \\
\hline Pot.bromate + taurine group & $16.8 \pm 2.1 \mathrm{a}$ & $32.5 \pm 0.18 \mathrm{a}$ & $34.5 \pm 0.23 \mathrm{a}$ & $1.8 \pm 0.3 \mathrm{a}$ \\
\hline Pot.bromate + vanillin group & $17 \pm 2.02 \mathrm{a}$ & $31.03 \pm 2.06 \mathrm{a}$ & $30.65 \pm 1.7 \mathrm{a}$ & $2.1 \pm 0.3 \mathrm{a}$ \\
\hline Pot bromate + taurine + vanillin & $18 \pm 1.99 \mathrm{a}$ & $31.06 \pm 1.8 \mathrm{a}$ & $31 \pm 2 \mathrm{a}$ & $2.3 \pm 0.7 \mathrm{a}$ \\
\hline
\end{tabular}

Values are expressed as mean \pm S.D., $n=6$

There was no significant difference between means have the same letter in the same column

testicular tissue. This decrease in the previously mentioned parameters was accompanied by a significant increase in MDA level in testicular tissue. Also, there was a significant decrease in total sperm count accompanied by a significant increase in the total number of malformed sperms (Head, tail, and head and tail) in the pot-bromate intoxicated group as shown in Table 2. Also, results in Table 3 reported that $\mathrm{KBrO}_{3}$ toxicity induces renal dysfunction manifested in a significant increase in serum urea, creatinine, and uric acid. The results also revealed that $\mathrm{KBrO}_{3}$ toxicity induced renal damage via oxidative stress indicated in a significant elevation in serum xanthine oxidase activity, renal Hcy, and MDA levels. The results also demonstrated a significant increase in renal pro-inflammatory cytokines TNF- $\alpha$ and IL- 6 in the pot bromate intoxicated group as compared to the normal control group as shown in Table 4. Finally, hematological results showed a significant decrease in $\mathrm{Hb} \%$, hemocrites (Hct), mean corpuscular volume (MCV), red blood corpuscles (RBCs), and white blood cells (WBCs) count in the pot-bromate intoxicated group as compared to normal control groups. Whereas, $\mathrm{MCH}$ concentration $(\mathrm{MCHC})$ and platelet count showed no significant difference between pot-bromate treated group and control group . However,

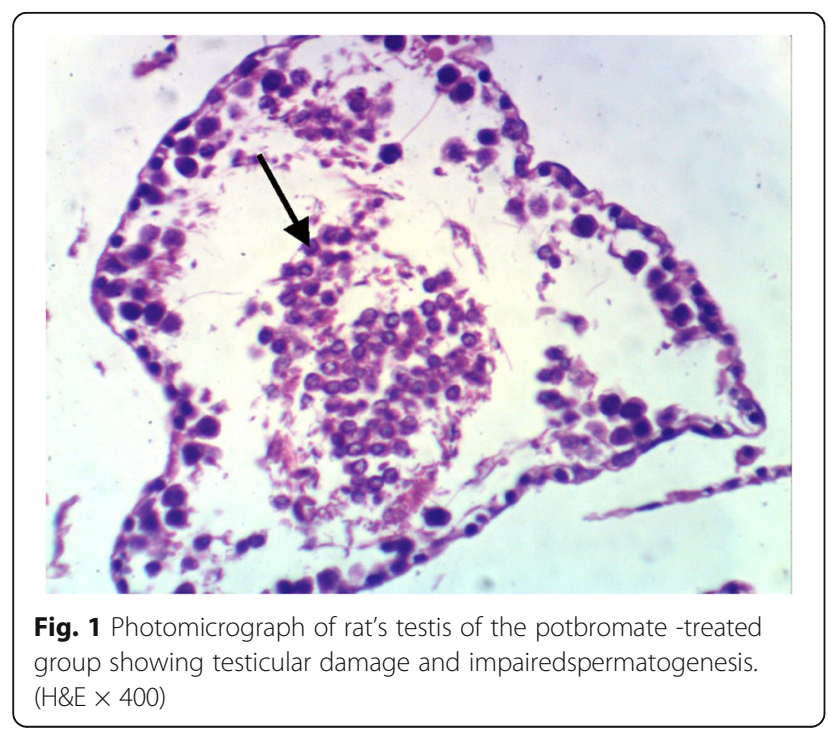

pre-treatment with taurine and/or vanillin showed a significant improvement in hematological parameters Tables 5, and 6).

Histological findings showed that $\mathrm{KBrO}_{3}$ toxicity impaired renal and testicular histology as shown in (Fig. 1 as compared to (Fig. 2) for testis and (Figs. 3 and 4) as compared to Fig. 5 for kidney that was concomitant with biochemical parameters. Pretreatment with either taurine or vanillin showed a partial recovery in seminiferous epithelium of testis as shown in (Figs. 6, 7 and 8). With respect to kidney, the histopathology results of $\mathrm{KBrO}_{3}$-treated rats showed inflammatory cell infiltration in the renal capsule, hypercellularity of glomerular tuft, a proteinaceous material in the lumen of renal tubules, and proteinaceous material in the Bowman's space and the lumen of renal tubules (Figs. 3 and 4). Pretreatment with either taurine or vanillin showed a slight congestion in of the glomerular tuft and congestion of renal blood vessel as shown in (Figs. 9, 10, 11, and 12). On the other hand, pretreatment with taurine and vanillin in combination showed a significant ameliorative effect against deleterious alterations associated with $\mathrm{KBrO}_{3}$ toxicity in testicular and renal tissues. Nearly normal histological

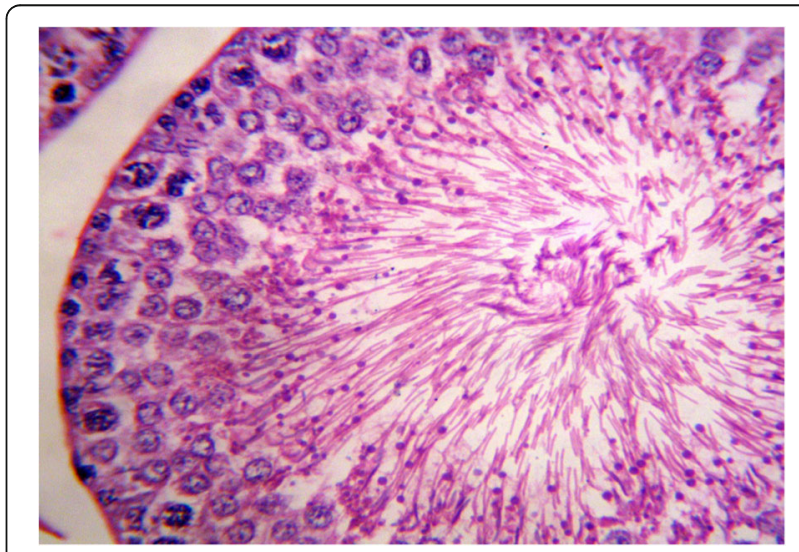

Fig. 2 Photomicrograph of rat's testis of control group rats, showing the normal histological structure (H \& E X 400) 


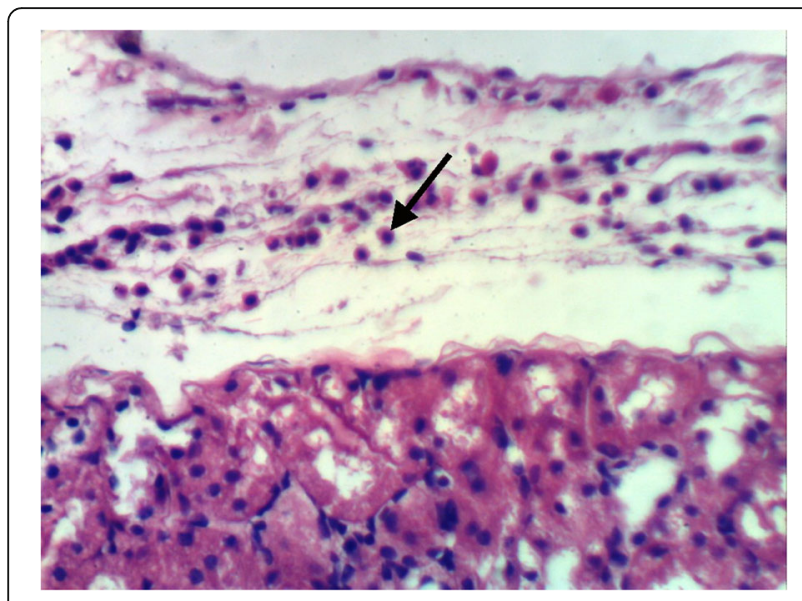

Fig. 3 Photomicrograph of rat's kidney fed the balanced diet and orally administered pot.bromateshowing proteinaceous material in the Bowman's space $(H \& E \times 400)$

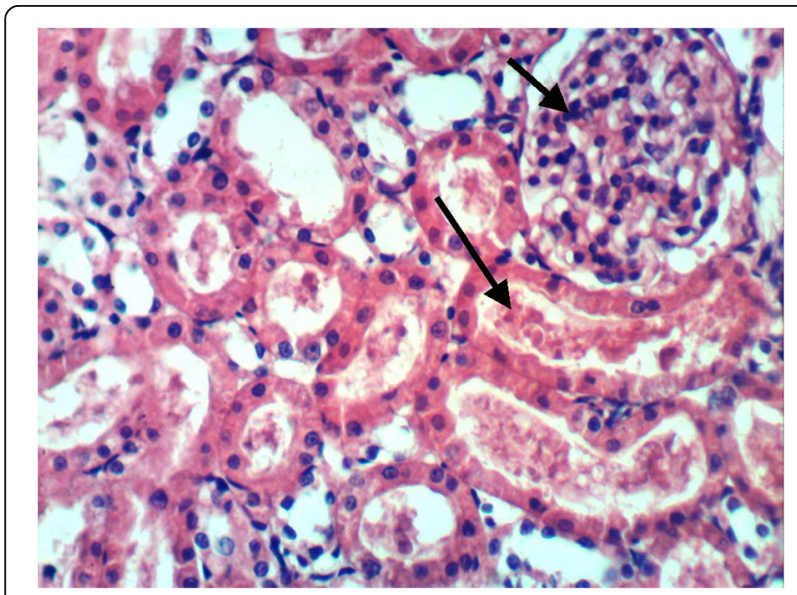

Fig. 4 Photomicrograph of rat's kidney fed the balanced diet and orally administered pot.bromateshowing hypercellularity of glomerular tuft $(H \& E \times 400)$

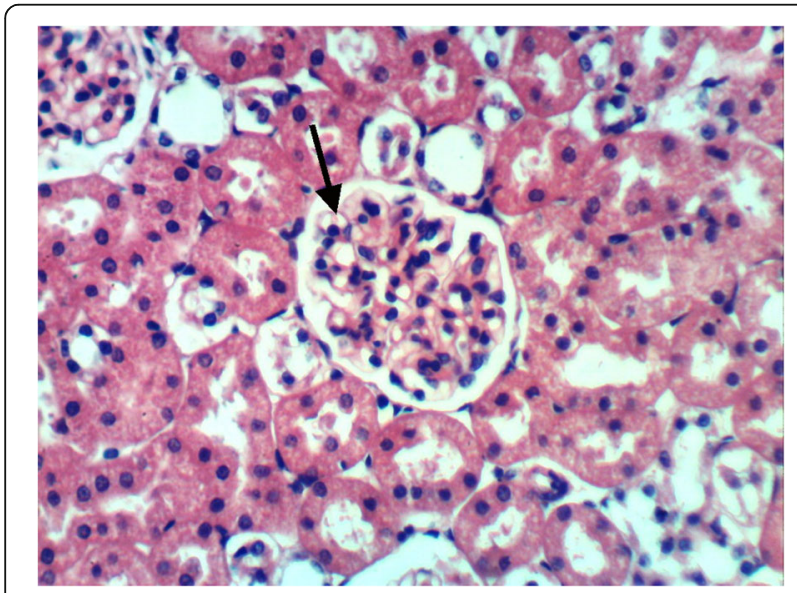

Fig. 5 Photomicrograph of normal control rats, showing the normal histological structure of renal parenchyma $(H \& E \times 400)$

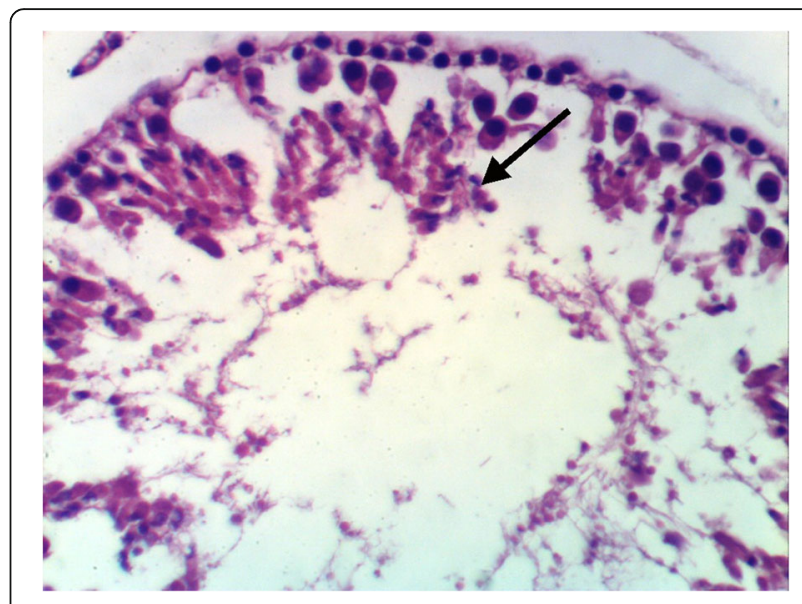

Fig. 6 Photomicrograph of rat's testis fed the balanced diet supplemented with taurine +oral pot.bromate, showing markedly decreased number of germ cells. $(H \& E \times 400)$

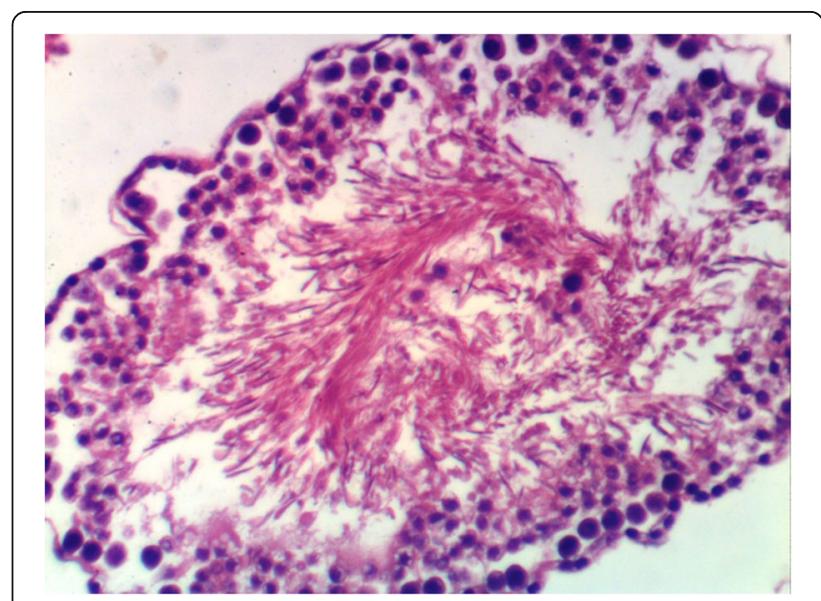

Fig. 7 Photomicrograph of testis of rat fed the balanced dietsupplemented with taurine +oral pot.bromateshowing detached germ cells, although the seminiferous epithelium is partially recovered (H\&E $\times 400)$

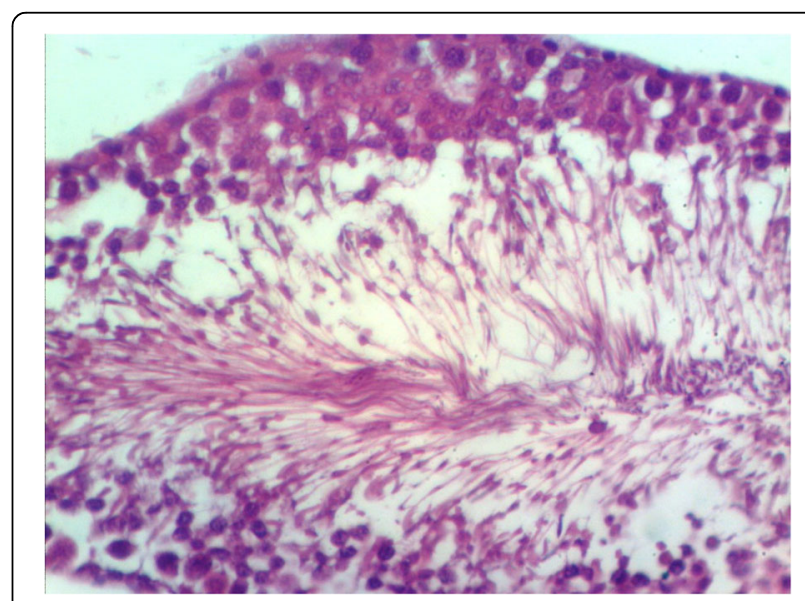

Fig. 8 Photomicrograph of rat's testis fed the balanced diet supplemented with vanillin+ oral pot.bromate showing minor testicular damage with partial depletion of germ cells (H\&E $\times 400)$ 


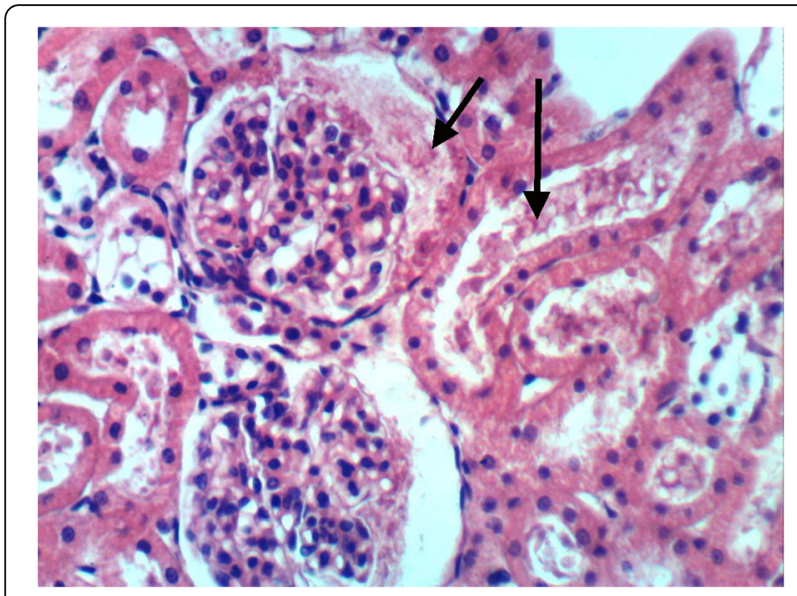

Fig. 9 Photomicrograph. of rat's kidney fed the balanced diet supplemented with taurine+pot.bromate,showing hypercellularity of glomerular tuft $(H \& E \times 400)$

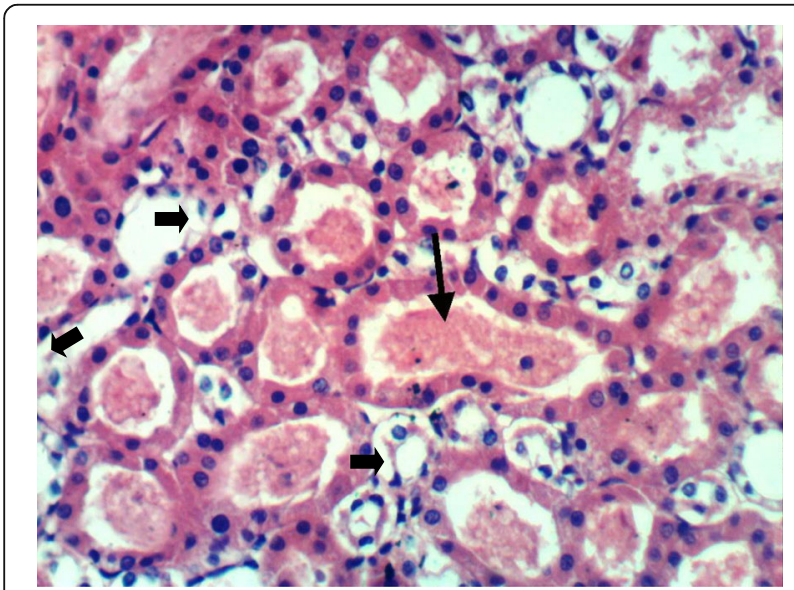

Fig. 10 Photomicrograph of rat's kidney fed on balanced diet supplemented with taurine+pot.bromate, showing proteinaceous material and degeneration of the cells lining in distal convoluted tubules $(H \& E \times 400)$

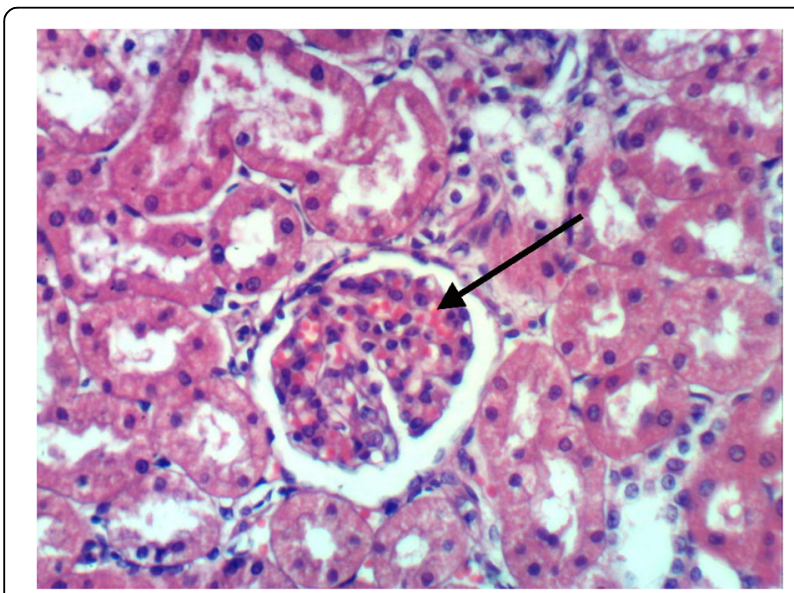

Fig. 11 Photomicrograph of rat's kidney fed the balanced diet supplemented with vaniilin + oral pot.bromate, showing slight congestion of the glomerular tuft $(H \& E \times 400)$

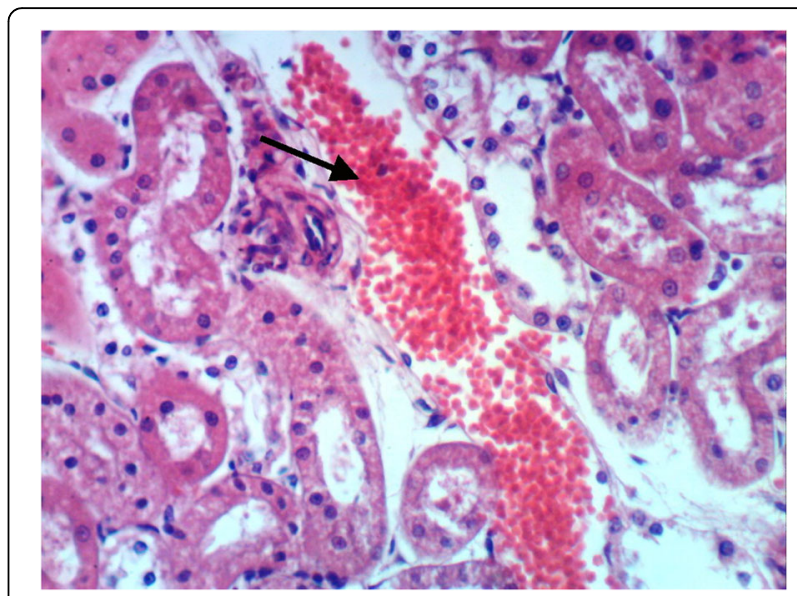

Fig. 12 Photomicrograph of rat's kidney fed the balanced diet supplemented with vanillin+oral pot.bromate, showing congestion of renal blood vessel $(H \& E \times 400)$

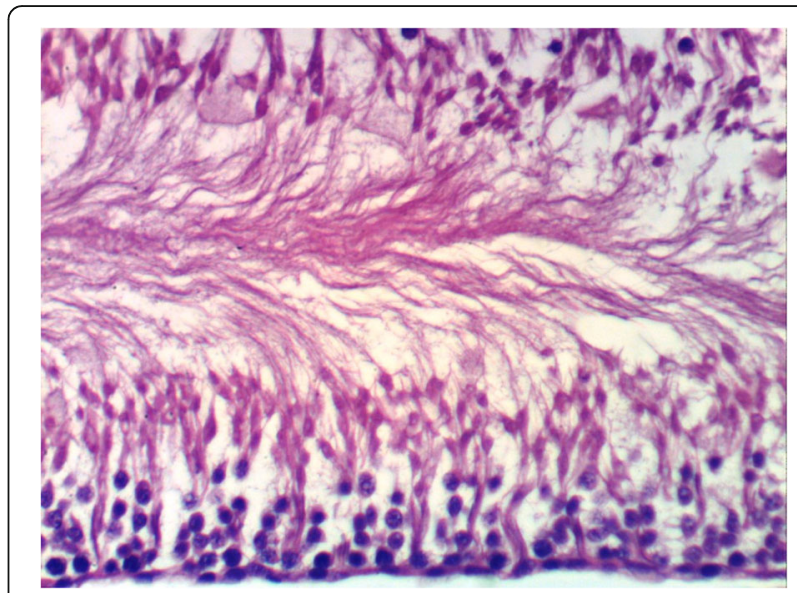

Fig. 13 Photomicrograph of rat's testis fed the balanced diet supplemented with taurine and vaniilin +oral pot.bromateshowing nearly normal histological structure with complete spermatogenesis $(H \& E \times 400)$

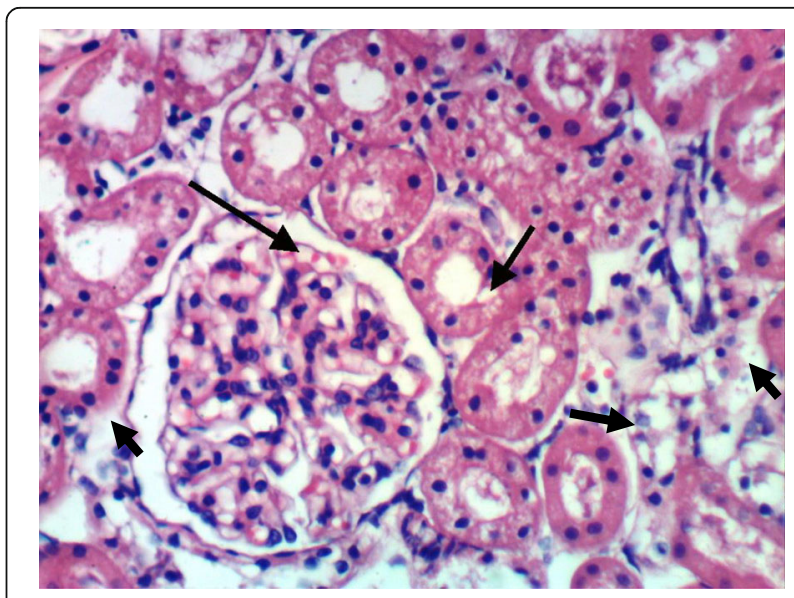

Fig. 14 Photomicrograph of rat's kidney fed on balanced diet supplemented with taurine and vanillin+ oral pot.bromateshowing almost normal structure of renal parenchyma $(H \& E \times 400)$ 
structure in the testicular section with complete spermatogenesis in (Fig. 13). Kidney of rat from group 5 showed almost normal structure of renal parenchyma with few degeneration of cell lining renal tubules (Fig. 14). Moreover, the best correction occurred in the animal group which was treated with both of them; this may be due to their synergistic effect.

\section{Discussion}

The current study was attempted to examine the protective role of pre-treatment with taurine and/or vanillin in attenuating the deleterious effects of $\mathrm{KBrO}_{3}$-induced oxidative stress in testis, kidney, and hematology. Taurine and vanillin were selected as dietary compounds which are found in several foods and exhibits protective effects against certain environmental agents because of their antioxidant properties (Das, Roy, \& Sil, 2012) and (Al Asmari, Al Shahrani, Al Masri, Al Faraidi, Elfaki, \& Arshaduddin, 2016). The use of such dietary compounds like taurine or vanillin offers a great potential as they are part of the normal diet and can be safely taken by persons who are at risk of exposure to toxicants.

Testicular secretory constituents like glycogen, total protein, and sialic acid are valuable in evaluating testicular functional capacity (Gupta, Kachhawa, \& Chaudhary, 2004). Protein biosynthesis is vital in spermatogenesis and testicular development. Sertoli cells regulate the spermatogenic process of synthesizing proteins required for germ cell maturation (Weinbauer, Luetjens, Simoni, \& Nieschlag, 2010). The reduction in testicular protein content in the positive control group may be attributed to disturbances in protein synthesis or metabolism induced by $\mathrm{KBrO}_{3}$ toxicity. The previous results of Geeta and Gyan (2015) supported the results of the current study reporting that $\mathrm{KBrO}_{3}$ toxicity induced a significant decrease in protein content in the testis.

Glycogen is a crucial requirement for proper testicular functioning and development; it acts as a modulator of germ cell survival (Villarroel-Espíndola et al., 2013). The decreased testicular glycogen in the pot-bromate intoxicated group may be due to inhibition of enzyme activity in the synthesis of glycogen. Reduction in glycogen level after $\mathrm{KBrO}_{3}$ administration inhibited the glycogen synthesis, which eventually decreases spermatogenesis (Joshi, Mathur, \& Gulati, 2007).

Sialic acid is a derivative of $\mathrm{N}$-acetylmannose and an important constituent of glycolipids and glycoproteins. Results demonstrated that $\mathrm{KBrO}_{3}$ toxicity induced a significant decrease in testicular sialic acid as compared to the normal control group. This decline in testicular sialic acid level may be due to a decrease in the rate of spermatogenesis. The result of the current study supported by the previous results of Nwonuma, Irokanulo, Iji, Alejolowo, and Adetunji (2016) reported a significant decrease in testicular glycogen, total protein, and sialic acid in the pot-bromte intoxicated rats. However, the pretreated groups with taurine and/or vanillin showed a recovery in protein,glycogen, and sialic acid levels, which may imply that these compounds have the potential to enhance synthesis of testicular secretory constituents.

$\mathrm{KBrO}_{3}$ toxicity induces a significant increase in MDA level in testicular tissue as compared to control group. Whereas, pretreatment with taurine and/or vanillin restored MDA to levels more or less similar to that of control group rats. The deterioration in sperm biochemical parameters might be correlated with enhanced lipid peroxidation. The results obtained by Acharya, Mishra, Patro, and Panda (2008) supported the results of the current study reporting that generation of reactive oxygen species (ROS) by $\mathrm{KBrO}_{3}$ toxicity and subsequent oxidative impairment may increase sperm deformation. However, supplementation with taurine and/or vanillin led to a significant elevation in total sperm count concomitant with a significant decrease in malformed sperm (total, head, tail, and head and tail). This improvement in spermatic profiles could be attributed to the antioxidant property of taurine and/or vanillin, which may induce an increase in testicular spermatogenesis indicating elevation in differentiated germ cells number.

These data are in harmony with those obtained from Hassanein (2011)who attributed the elevation in the total number of sperms correction in the number of malformed sperms (total, head, tail, and head and tail) after treatement with taurine to the antioxidant potential of taurine which acts to scavenge free radicals and decrease lipid peroxidation production. Similar results obtained from Abdel-Twab, Mohamed, and Mahmoud (2016) and Mohamed and Gawad (2017) confirmed that taurine intake showed a significant improvement in the sperm counts and motility, degenerative changes of the seminiferous tubules, and spermatogenesis.

The histopathological finding of testis strongly supports the alterations in biochemical parameters of the testicular function. The histopathological observations showed testicular cellular degeneration and subsequently impaired spermatogenesis in positive control compared to taurine and/or vanillin pretreated animals which showed normal cell due to their protective effect. The results of Gameel, Aboagla, Fadul, and Elsheik (2016) are in accordance with the result of the current study. The author reported that exposure to $\mathrm{KBrO}_{3}$ alters the histology of the rat testis and impaired spermatogenesis. The antioxidant effect of taurine and its protective effect against apoptosis and germ cell degeneration resulting from testicular torsion was reported by Aydos, Başar, Kul, Atmaca, Uzunalioğlu, Kisa, \& Efe, 2014).

Renal injury due to $\mathrm{KBrO}_{3}$ intoxication could be evaluated by assessment of serum urea, creatinine, and uric acid, 
which were used as early indicators of renal dysfunction (Nabavi et al., 2013). The significant increase in serum urea, creatinine, and uric acid in the pot bromate-treated rats indicate the development of renal dysfunction and reduced glomerular filtration rate. The increase in uric acid level also may be due to degradation of purines and pyrimidines which strongly related to the significant increase in xanthine oxidase activity resulted in overproduction of uric acid. The increase in xanthine oxidase activity does not only catalyze the formation of uric acid but also generate ROS. Therefore, the elevated xanthine oxidase activity could explain the association between pot-promote toxicity and both hyperuricemia and increased ROS production.

Additionally, homocysteine at elevated levels is associated with oxidative stress and lipid peroxidation leading to renal cell damage Zhang, YLand, \& Kamin, 2004). The free sulfhydryl group of homocysteine is auto-oxidized and generates reactive oxygen species such as superoxide and hydrogen peroxide. That liberated ROS could initiate lipid peroxidation (Wang, Tan, \& Yang, 2005).

In the present investigation, $\mathrm{KBrO}_{3}$-treated rats exhibited a higher renal homocysteine and lipid peroxide level as compared to the negative control group, clearly signifying the existence of oxidative stress. This increase in lipid peroxidation may lead to a progressive diminution of glomerular function eventually leading to renal dysfunction. However, pretreatment with taurine and or vanillin significantly decreased the level of homocysteine and lipid peroxides (MDA) in renal tissue. This normalization may be due to free radical quenching nature of taurine and/or vanillin, preventing the lipid peroxidation. In the same trend, results of Oliveira et al. (2014) and Al Asmari et al. (2016) reported that vanillin, like other polyphenols of plants, is a potent free radical scavenger as it contains different functional groups including the phenolic group.

Pro-inflammatory cytokines, including tumor necrosis factor- $\alpha$ (TNF- $\alpha$ ) and interleukin- 6 (IL-6), are thought to act as a central factor in the pathophysiology of chronic kidney disorders (Stenvinkel, Ketteler, \& Johnson, 2005). ROS can induce inflammatory processes by activation of transcription factors, which induce secretion of pro-inflammatory cytokines including IL-6 and TNF- $\alpha$ (Valério et al., 2009).

In this study, results illustrated that $\mathrm{KBrO}_{3}$ induced an inflammatory reaction indicated by increasing renal TNF- $\alpha$ and IL-6 levels. However, treatment with taurine and/or vanillin prior $\mathrm{KBrO}_{3}$ administration suppressed the overproduction of TNF- $\alpha$ and IL- 6 in renal tissue provided a protective effect against kidney pathological changes.

Interestingly, the observed results show that pretreatment of rats with vanillin also caused the apparent reduction in levels of proinflammatory cytokines such as IL-6 and TNF- $\alpha$. This is in accordance with the previous results obtained by Katary and Salahuddin (2017) who reported that pre-treatment with vanillin resulted in a normalization in tissue gastric levels of inflammatory cytokines TNF- $\alpha$ in indomethacin-induced gastric ulcer rats indicating the anti-inflammatory action of vanillin.

The histopathology results of $\mathrm{KBrO}_{3}$-treated rats showed pathological alterations in the renal capsule, the Bowman's space, and the lumen of renal tubules. On the other hand, pretreatment with taurine and/or vanillin markedly ameliorated the significant pathological changes provoked by $\mathrm{KBrO}_{3}$ administration. This could be attributed to the antioxidant and anti-inflammatory potential of taurine and/or vanillin, which significantly reduced the oxidative stress, leading to restoration of the normal physiological state of kidney cells. Further, membrane-stabilizing properties of taurine may provide additional improvements in these pathological alterations in renal tissue of the $\mathrm{KBrO}_{3}$-treated rats. Similar observations have been reported in the previous study of Ben Saad et al. (2016) which confirmed that vanillin treatment $(100 \mathrm{mg} / \mathrm{kg} /$ day for 15 days) restored histopathological changes in $\mathrm{KBrO}_{3}$-induced kidney damage.

In the present study, it was observed that $\mathrm{KBrO}_{3}$-induced hematological changes which were ameliorated in the group pretreated with taurine and/or vanillin. Decreased RBC counts observed in the present study may be due to harmful effects of $\mathrm{KBrO}_{3}$ on bone marrow and hematopoietic organs. Moreover, oxidative stress plays a major role in damaging the $\mathrm{RBC}$ membrane and subsequent impairing its deformability. Oxidative stress also contributes to the removal of deformed RBCs from circulation by macrophages (Mohanty, Nagababu, \& Rifkind, 2014).Whereas, Hb and Hct concentrations may have been associated with the formation of methemoglobin, a form of $\mathrm{Hb}$, which has a decreased ability to bind oxygen. Corroborating with these results of Dhembare and Dale (2017) revealed that $\mathrm{KBrO}_{3}$ treatment induces a significant decrease in $\mathrm{Hb}$, Hct, and $\mathrm{MCV}$ values with the concomitant decrease in WBCs and RBCs count.

From the obtained results, it is clear that pretreatment with taurine and/or vanillin restored alterations induced by $\mathrm{KBrO}_{3}$ toxicity in hematological parameters. In the same trend of the results of the current study, Ahmad and Mahmood (2014) reported that the protective effect of taurine administration $\mathrm{KBrO}_{3}$ against $\mathrm{Hb}$ oxidation and oxidative stress induced by $\mathrm{KBrO}_{3}$ treatment. Also, the potential protective effect of vanillin on hematological parameters against alterations induced by metribuzin was demonstrated in a study by (Messarah et al., 2017).

\section{Conclusions}

Pretreatment with taurine and/or vanillin showed a significant ameliorative effect against deleterious alterations associated with $\mathrm{KBrO}_{3}$ toxicity in hematological parameters, renal and testicular tissues. Moreover, the recorded improvement in the studied parameters of rats pretreated with both antioxidants in combination proves their synergistic effect. 


\section{Abbreviations}

Hct: Hemocrites; IL-6: Interleukin-6; $\mathrm{KBrO}_{3}$ : Potassium bromate; $\mathrm{MCH}$ : Mean corpuscular hemoglobin; MCHC: MCH concentration; MCV: Mean corpuscular volume; MDA: Malondialdehyde; RBCs: Red blood corpuscles; ROS: Reactive oxygen species; TNF-a: Tumor necrosis alpha; WBCs: White blood cells

\section{Acknowledgements}

The authors are greatly thankful to Prof. Dr. Mai Helmy Abdel-Gawad professor in Zoology Department, Faculty of Women's For Art, Science And Education, Ain Shams University, Egypt and prof. Dr.Kawkab, A Ahmed, professor of pathology, pathology department, veterinary medicine, Cairo University for their helping in histological examination

\section{Funding}

This research did not receive any specific grant from funding agencies in the public, commercial, or not-for-profit sectors.

\section{Availability of data and materials}

The datasets supporting the conclusions of this article are included within the article and its additional files.

\section{Authors' contributions}

All authors participated in all parts of the research. All authors read and approved the final manuscript.

\section{Ethics approval}

This study follows the Declaration of Helsinki and the guidelines for the care and use of experimental animals established by the Committee for the Purpose of Control and Supervision of Experiments on Animals. Animal procedures were also made in accordance with the National Institutes of Health $(\mathrm{NIH})$ protocol approved by Ain Shams University.

\section{Consent for publication}

Not applicable.

\section{Competing interests}

The authors declare that they have no competing interests.

\section{Publisher's Note}

Springer Nature remains neutral with regard to jurisdictional claims in published maps and institutional affiliations.

\section{Received: 26 August 2018 Accepted: 11 December 2018}

\section{Published online: 23 January 2019}

\section{References}

Abdel-Twab, S., Mohamed, H., \& Mahmoud, A. (2016). Taurine and pioglitazone attenuate diabetes-induced testicular damage by abrogation of antioxidative stress and up-regulation of the pituitary-gonadal axis. Canadian Journal of Physiology and Pharmacology, 94, 651-661.

Acharya, U. R., Mishra, M., Patro, J., \& Panda, M. K. (2008). Effect of vitamins C and E on spermatogenesis in mice exposed to cadmium. Reproductive Toxicology, $25,84-88$.

Ahmad, M. K., \& Mahmood, R. (2016). Protective effect of taurine against potassium bromate-induced hemoglobin oxidation, oxidative stress, and impairment of antioxidant defense system in blood. Environmental Toxicology, 31, 304-313.

Ahmad, M. K., Naqshbandi, A., Fareed, M., \& Mahmood, R. (2012). Oral administration of a nephrotoxic dose of potassium bromate, a food additive, alters renal redox and metabolic status and inhibits brush border membrane enzymes in rats. Food Chemistry, 134, 980-985.

Ahmad, M. K., Zubair, H., \& Mahmood, R. (2013). DNA damage and DNA-protein cross-linking induced in rat intestine by the water disinfection by-product potassium bromate. Chemosphere, 91, 1221-1224.

Al Asmari, A., Al Shahrani, H., Al Masri, N., Al Faraidi, A., Elfaki, I., \& Arshaduddin, M. (2016). Vanillin abrogates ethanol-induced gastric injury in rats via modulation of gastric secretion, oxidative stress and inflammation. Toxicology Reports, 3, 105-113.

Aydos, T., Başar, M., Kul, O., Atmaca, H., Uzunalioğlu, T., Kisa, U., \& Efe, O. (2014). Effects of ozone therapy and taurine on ischemia/reperfusion-induced testicular injury in a rat testicular torsion model. Turk. J. Med. Sci, 44, 749-755.
Barham, D., \& Trinder, P. (1972). Enzymatic colorimetric methods for determination of uric acid in serum, plasma and urine. Analyst, 97, 14.

Belsey, M. A., Moshissi, K. S., Eliasson, R., Paulsen, C. A., Gallegos, A. J., \& Prasad, M. R. (1980). Laboratory manual for the examination of human semen and semen-cervical mucus interaction. Press concern, 72-82.

Ben Saad, H., Driss, D., Chaabouni, S. E., Boudawara, T., Zeghal, K. M., Hakim, A., \& Ibtissem Ben Amara, I. (2016). Vanillin mitigates potassium bromate-induced molecular, biochemical and histopathological changes in the kidney of adult mice. Chemical-Biological Interactions, 252, 102-113.

Beutler, B., Greenwald, D., \& Hulmes, J. D. (1985). The identity of tumour necrosis factor and the macrophage-secreted factor cachectin. Nature, 316, 552-554.

Bezerra, D. P., Nascimento Soares, A. K., \& de Sousa, D. P. (2016). Overview of the role of Vanillin in redox status and cancer development. Oxide MED Cell Longev, 2016, 9734816.

Dalrymple, R. H., \& Hamm, R. (1973). A method for the extraction of glycogen and metabolites from a single muscle sample. International Journal of Food Science and Technology, 4, 439-444.

Das, J., Roy, A., \& Sil, P. C. (2012). Mechanism of the protective action of taurine in toxin and drug-induced organ pathophysiology and diabetic complications. Food \& Function, 3, 1251-1264.

Dhembare, A. J., \& Dale, P. G. (2017). Potassium bromate induced a hematological alteration in European rabbit. The Journal of Zoology Studies, 4, 01-05.

El-Houseini, M. E., El-Agoza, I. A., Sakr, M. M., \& El-Malky, G. M. (2017). Novel protective role of curcumin and taurine combination against experimental hepatocarcinogenesis. Exp Ther Me., 13, 29-36.

Gameel, A. A., Aboagla, E. M., Fadul, T. F., \& Elsheik, A. S. (2016). Effects of potassium bromate on male rat growth and testicular histology. Asian Pacific Journal of Reproduction, 5, 376-380.

Geeta, P., \& Gyan, C. J. (2015). Assessment of molybdenum induced alteration in oxidative indices, biochemical parameters and sperm quality in testis of Wistar male rats. Asian Journal of Biochemistry, 10, 267-280.

Gupta, R. S., Kachhawa, J. B., \& Chaudhary, R. (2004). Antifertility effects of metabolic pod extract of Albizzia lebbeck. Asian Journal of Andrology, 6, 155-159.

Hassanein, M. S. (2011). The curative role of taurine or zinc and their mixture on the harmful effects of Genistein administration in male rats. The Egyptian Journal of Medical Sciences, 20, 613-631.

Henry, R. J., Cannon, D. C., \& Winkelman, J. W. (1974). Clinical chemistry principles and techniques, (pp. 116-140). New york: Harper and Row.

Joshi, S. C., Mathur, R., \& Gulati, N. (2007). Testicular toxicity of chlorpyrifos (an organophosphate pesticide) in the albino rat. Toxicology and Industrial Health, 23, 439-444.

Katary, M. A., \& Salahuddin, A. (2017). Gastroprotective effect of vanillin on indomethacin-induced gastric ulcer in rats: Protective pathways and anti-secretory mechanism Katary MA1 and Salahuddin A2. Clinical and Experimental Pharmacology, 7, 1-8.

Kim, S. J., Gupta, R. C., \& Lee, H. W. (2007). Taurine-diabetes interaction: from involvement to protection. Current Diabetes Reviews, 3, 165-175.

Lourenco, R., \& Camilo, M. E. (2002). Taurine: a conditionally essential amino acid in humans? An overview of health and disease. Nutrición Hospitalaria, 17, 262-270.

Messarah, M., Kadee, L., Bourogaa, E., Saudi, M., Blumenfeld, A., Djeffal, A., et al. (2017). Ameliorative effects of vanillin against Metribuzin-induced oxidative stress and toxicity in rats. Int J Pharm Pharm SC, 9, 56-56.

Mohamed, N. A. ., \& Gawad, H. S. A. (2017). Taurine dietary supplementation attenuates brain, thyroid, testicular disturbances and oxidative stress in streptozotocin-induced diabetes mellitus in male rats. Beni-Suef Univ. J. Basic Appl. SCl, 6, 247-252

Mohanty, J.G., Nagababu, E., Rifkind, J.M., 2014 Red blood cell oxidative stress impairs oxygen delivery and induces red blood cell ageing. Frontiers in Physiology,28;5:84. Do: https://doi.org/10.3389/fphys.2014.00084.

Nabavi, S. M., Habtemariam, S., Navabi, S. F., Suerda, A., Moghaddam, A. H., \& Amani, M. A. (2013). The protective effect of garlic acid isolated from Peltiphyllum peltatum against sodium fluoride-induced oxidative stress in rat's kidney. Molecular and Cellular Biochemistry, 372, 233-239.

Nwonuma, C. O., Irokanulo, E. O., lji, C. E., Alejolowo, O. O., \& Adetunji, C. O. (2016). Effect of Thaumatococcus daniellii leaf rat-feed on potassium bromate-induced testicular toxicity. Asian Pacific Journal of Reproduction, 5, 500-505.

Ohkawa, H., Ohishi, W., \& Yagi, K. (1979). Assay of lipid peroxide in animal tissue by thiobarbituric acid. Anal. Biochem1, 95, 351-358.

Oliveira, C. B. S., Meurer, Y. S. R., Oliveira, M. G., Medeiros, W. M. T. Q., Silva, F. O. N., \& Brito, A. C. F. (2014). Comparative study on the antioxidant and anti-toxoplasma activities of vanillin and its resorcinarene derivative. Molecules, 19, 5898-5912. 
Oloyede, O. B., \& Sunmonu, T. O. (2009). Potassium bromate content of selected bread samples in llorin, Central Nigeria and its effect on some enzymes of rat liver and kidney. Food and Chemical Toxicology, 47, 2067-2070.

Priefert, H., Rabenhorst, J., \& Steinbuchel, A. (2001). Biotechnolog ical production of vanillin. Applied Microbiology and Biotechnology, 56, 296-314.

Reeves, G., Nielsen, F. H., \& Fahey, J. G. (1993). AlN-1993 reformation of the AlN-76: Purified diet for laboratory rodents: final report of the American Institute of Nutrition, purified ad-hoc writing committee on the reformation of the AlN-76 a rodent diet. American institute, J. Nutr, 26, 1939-1951.

Rock, R. C., Walker, W. G., \& Jennings, C. D. (1987). Nitrogen metabolites and renal function. In N. W. Tietz (Ed.), Fundamentals of clinical chemistry, (3rd ed., pp. 669-704). Philadelphia: WB Saunders.

Shoeb, A., Chowta, M., Pallempati, G., Rai, A., \& Singh, A. (2013). Evaluation of antidepressant activity of vanillin in mice. Indian J Pharmacol, 45, 141-144. https://doi.org/10.4103/0253-7613.108292.

Stenvinkel, P., Ketteler, M., \& Johnson, R. J. (2005). IL-10, IL-6, and TNF alpha: central factors in the altered cytokine network of uremia - the good, the bad, and the ugly. Kidney International, 67, 1216-1233.

Tobacco, A., Meiattini, F., Moda, E., \& Tarii, P. (1979). Simplified enzymatic/calorimetric serum urea nitrogen determination. J Clinical Chemistry, 25, 336-337.

Valério, D. A., Georgetti, S. R., Magro, D. A.r Casagrande, R., Cunha, T. M., Vicentini, F. T., et al. (2009). Quercetin reduces inflammatory pain: inhibition of oxidative stress and cytokine production. Journal of Natural Products, 72, 11975-11979.

Villarroel-Espíndola, F., Maldonado, R., Mancilla, H., Stelt, K. V., Acuna, A. Covarrubias, A., et al. (2013). Muscle glycogen synthase isoform is responsible for testicular glycogen synthesis: glycogen overproduction induces apoptosis in male germ cells. Journal of Cellular Biochemistry, 114, 1653-1664.

Wang, H., Tan, H., \& Yang, F. (2005). Mechanisms in homocysteine-induced vascular disease. Drug Discov Today (Dis Mech), 2, 25-31.

Weinbauer, G. F., Luetjens, C. M., Simoni, M., \& Nieschlag, E. (2010). Physiology of testicular function Nieschlag (Ed.), andrology, (pp. 11-59). Berlin: Springer Berlin Heidelberg.

Wong, G. G., \& Clark, S. C. (1988). Multiple actions of interleukin 6 within a cytokine network. Immunology Today, 9, 137-139.

Yao, K., Obuka, T., Mosuka, M., Kinuta, M., \& Ikeda, T. (1989). Direct determination of bound sialic acids in sialoglycoproteins of the acidic Ninhydrine reaction. Analytical Biochemistry, 179, 332-335.

Zamzuri, N. A., \& Abd-Aziz, S. (2013). Biovanillin from agro wastes as an alternative food flavour. Journal of the Science of Food and Agriculture, 93(3), 429-438.

Zhang, F., YLand, S., \& Kamin, O. (2004). Hyperhomocysteinemia activates NF-kappaB and inducible nitric oxide synthase in the kidney. Kidney International, 65, 1327-1338.

\section{Submit your manuscript to a SpringerOpen ${ }^{\circ}$ journal and benefit from:}

- Convenient online submission

- Rigorous peer review

- Open access: articles freely available online

- High visibility within the field

- Retaining the copyright to your article

Submit your next manuscript at $\boldsymbol{\nabla}$ springeropen.com 